Proceedings of the New Zealand Grassland Association 54: 23-26 (1992)

\title{
Deer production from ryegrass- and tall fescue-based pastures
}

\author{
D.R. STEVENS*, K. DREW², F. LAAS ${ }^{2}$ and J.D. TURNER' \\ AgResearch \\ 'Gore Research Centre, Private Bag 50022, Gore \\ ${ }^{2}$ Invermay Agriculture Centre Private Bag 50034. Mosgiel
}

\begin{abstract}
The development of a Appellation Marketing S egy by the New Zealand Game Industry Board will change the requirements of the venison industry. High deer liveweight gains throughout the year will be required to ensure a consistent supply of high quality venison. The improvement of spring and summer pasture availability and quality are being investigated at the Invermay Agricultural Centre. Tall fescue (Festuca arundinacea Schreb.) and tall fescue/chicory/(Cichorium intybus L.) red clover (Trifolium pratense L.) pastures were compared with high and low endophyte ryegrass (Lolium perenne L.) pastures. Liveweight gain and carrying capacity were measured in spring and summer one year after establishment. Pasture parameters were measured to explain differences in animal performance. Liveweight gain was similar on all treatments, though was $21-35 \%$ lower in summer than in spring. The tall fescue-based pastures had significantly higher carrying capacities because of a better clover balance throughout the trial. This led to significantly higher per ha production on first year tall fescue-based pastures. Though ryegrass endophyte had no effect on pasture or animal production, animal behaviour might have been affected.
\end{abstract}

Keywords Acremonium lolii, carrying capacity, Cichorium intybus, deer, Festuca arundinacea, liveweight gain, Lolium perenne, pasture parameters, Trifolium pratense, Trifolium repens

\section{Introduction}

The development of an Appellation Marketing Strategy by the New Zealand Game Industry Board is well underway with its launch in USA and NZ being timed for early 1993. The result of this strategy will be a Product Definition or a standard of meat quality which will have to be met by venison producers throughout the year. Already the pre-Christmas boom in venison demand through traditional markets is waning, as is reflected by the comparison of 1991-92 prices with the previous two seasons (The Deer Farmer June 1992). Pasture produc- tion and quality can inhibit the production of a high quality venison product especially as they decline in rat-summer (Adam 1988). Ryegrass staggers can also be a major cause of poor deer growth in summer.

Southern New Zealand is no exception to these problems. A cool moist climate supplies adequate summer rainfall. Ryegrass growth continues but deer can still suffer from ryegrass staggers in some years. Pasture availability and quality decline are both still a problem in ryegrass pastures during summer after heading.

Theuse of low endophyteryegrass can be advocated in southern New Zealand as good yields continue without major long term damage from Argentine stem weevil (Stevens \& Hickey 1989). However, tall fescue may be a better alternative for deer production, as it has been reported to have higher summer quality than ryegrass (McFarlane 1990). The incorporation of high quality species such as chiwry and red clover may also help alleviate the decline in summer pasture availability and quality improving deer production, as they are both highly preferred when grazed by deer (Hunt \& Hay 1980).

These options were tested to improve the growth rate of yearling deer in spring and summer by changing the pasture species. As production requirements change to meet appellation standards, surplus yearling hinds will also be required to provide a constant supply of product throughout the breeding season. Both hinds and stags were used to estimate the relative production differences between low and high endophyte ryegrass. tall fescue and tall fescue/chicory/red clover pastures. Pasture production data were collected to provide explanations for differences in animal production.

\section{Methods}

Four pasture mixtures were sown into a cultivated seedbed with $3 \mathrm{~kg} / \mathrm{ha}$ Grasslands Tahora white clover (Trifolium repens L.) on 26 October 1990 in 2 replicates of 0.65 ha individually fenced plots at the Jnvermay Agricultural Centre. The pasture types were Grasslands Nui high endophyte $(80 \%)$ ryegrass (Lolium perenne L.). Grasslands Nui low endophyte $(6 \%)$ ryegrass, Grasslands Roa tall fescue (Festuca arundinacea Schreb.), and Roa tall fescue/Grasslands Puna chicory (Cichorium intybus)/Grasslands Pawera red clover (Trifolium prat- 
ense L.) sown at 15.15 .20 and $10 / 1.5 / 4 \mathrm{~kg} / \mathrm{ha}$ respectively. All grass seed was superstrike treated and sown with $100 \mathrm{~kg} / \mathrm{ha}$ superphosphate (0-9-0-1 1).

Plots were lightly grazed during establishment with weeds being controlled by residual topping. During autumn and winter plots were rotationally grazed with hinds, with pastures containing chicory being only lightly grazed in dry conditions.

The measurement of the trial began in early October and continued until late February when behaviourial problems of the impendmg rut became apparent. Each plot was subdivided into four with electric fences and grazed rotationally from an available dry matter yield of $2500-3500 \mathrm{~kg} / \mathrm{ha}$ to a residue of $1200-1600 \mathrm{~kg} / \mathrm{ha}$. Stocking rate was varied fortnightly to maintain these pasture conditions. Water was supplied at all times.

The rotation cycle was initially 28 days but was reduced to 20 days during peak November and December growth. The rotation length on the ryegrass treatments was increased back to 28 days after mid December, and stock numbers reduced because of slower pasture recovery. Tall fescue pastures maintained a 20\&y rotation until the trial end. Seedhead development was controlled by mechanical topping between December and early February.

The yearling stags and hinds were weighed at 2week intervals and a core of 10 animals remained on each plot throughout. Stags were velveted at optimum commercial values and regrowth removed in February. Only stag liveweight gains are presented, and stocking rates are expressed as stag equivalents ( 1 hind $=0.83$ stags). Spring data were obtained from 72 days to 12 December and summer data from 70 days to 22 February.

Botanical analysis was performed monthly from October to February (during the trial period) for the pregrazing herbage mass. Spring means were derived from October and November measurements and summer from December, January and February measurements. The sown grass, chicory, red and white clover content and other species (mainly Poa annua) were expressed as a percentage of the green fraction of the sward. Dead material was expressed as a percentage of the total sward. Ryegrass endophyte levels were sampled in March 1992 from each plot.

\section{Results}

\section{Pasture parameters}

Plant establishment in all plots was good although Roa tall fescue seedling numbers when planted in association with Puna chicory and Pawera red clover were half those in the tall fescue-alone plots because of a lower seeding rate. Tall fescue tiller numbers (Table 1) at the end of winter were lower than in the ryegrass treatment when analysed by orthogonal contrasts. This was again mainly accounted for by the lower sowing rate of tall fescue in the mixture. The number of clover growing points was significantly greater in the tall fescue than the ryegrass treatments (Table 1 ).

Table 1 Tiller and clover growing point numbers in late winter 1991 and ryegrass endophyte levels in mid summer 1992.

Late Winter 1991

\begin{tabular}{|c|c|c|c|}
\hline \multirow[t]{2}{*}{ Treatment } & \multirow[b]{2}{*}{$\begin{array}{l}\text { Sown Grass } \\
\text { Tiller Nos } \\
\text { / }^{2}\end{array}$} & \multirow[b]{2}{*}{$\begin{array}{l}\text { Clover } \\
\text { growing } \\
\text { points } / \mathrm{m}^{2}\end{array}$} & \multirow{2}{*}{$\begin{array}{l}\text { Endophyte } \\
\text { Levels } \\
\% \text { of tillers } \\
\text { Infected }\end{array}$} \\
\hline & & & \\
\hline High endophyte ryegrass & 4900 & 1200 & 82 \\
\hline Low endophyte ryegrass & 4000 & 1300 & 12 \\
\hline Tall fescue & 3400 & 3100 & 0 \\
\hline Tall rescue/chicory/red clover & 2000 & 3700 & 0 \\
\hline Isd & 2800 & 1700 & \\
\hline
\end{tabular}

Ryegrass endophyte levels (Table 1) corresponded to the endophyte level of the seed sown. The ryegrass contamination of tall fescue plots was between 4 and $11 \%$ of the total dry matter production and $90 \%$ of these tillers were infected with endophyte. There were no endophyteeffects onpastureproductionorwmposition.

During spring ryegrass made up 8 1-90\% while tall fescue contributed only $3948 \%$ of the greenmaterial of the herbage before grazing (Table 2). White clover content of the ryegrass swards was only 8-1 $1 \%$ whereas tall fescue swards had $15-17 \%$. Chicory contributed $5 \%$ and red clover $16 \%$ to the green herbage mass. Other species were again low in ryegrass pastures (3-8\%) but made a significant contribution to tall fescue-based swards $(23-37 \%)$. Dead material was low in spring, ranging from $4-8 \%$ with no difference between ryegrass and tall fescue swards.

The botanical composition in summer shifted the most in ryegrass swards (Table 2). Ryegrass content declined to $64-65 \%$ while white clover content increased to $28-31 \%$ of the pre-grazing herbage mass. The contribution of the other species changed little. Tall fescue content did not alter significantly in summer but white clover wntent increased to $27-30 \%$ while the contribution of other species declined to $16-26 \%$ of the green pregrazing herbage mass. Chicory contribution in summer increased to $17 \%$ but red clover content declined to $5 \%$. Dead material in the summer was much higher than in spring, and was significantly greater in the ryegrass swards (27\%) than the tall fescue swards (16-23\%). 
Table 2 Botanical composition of the pastures in spring and summer. Sown grass. clover (red and white) and other species are expressed as the percentage of the green herbage on offer. Dead material is expressed as a percentage of the total herbage on offer

\begin{tabular}{|c|c|c|c|c|c|c|c|}
\hline & Sown Grass & White Clover & Red & Clover & Chlcory & Other Specles & Dead \\
\hline \multicolumn{8}{|l|}{ SPRING } \\
\hline High endophyte ryegrass & 90 & 8 & & & & 2 & 5 \\
\hline Low endophyte ryegrass & 81 & 11 & & & & 8 & 8 \\
\hline Tall Fescue & 46 & 15 & & & & 37 & 4 \\
\hline Tall fescue/chicory/red clover & 39 & 17 & & 16 & & 23 & 7 \\
\hline & . & . & & & & $t$ & $\therefore$ \\
\hline isd & 11 & 7 & & & & 5 & 6 \\
\hline \multicolumn{8}{|l|}{ SUMMER } \\
\hline High endophyte ryegrass & 65 & 31 & & & & 4 & 27 \\
\hline Low endophyte ryegrass & 64 & 26 & & & & 8 & 27 \\
\hline Tall Fescue & 44 & 30 & & & & 26 & 16 \\
\hline Tall fescue/chicory/red clover & 34 & 27 & & 5 & 17 & 17 & 23 \\
\hline & N S & N S & & & & $\cdot$ & $\therefore$ \\
\hline Isd & 30 & 30 & & & & 12 & 12 \\
\hline
\end{tabular}

\section{Animal Production}

Deer growth rates were not significantly higher from ryegrass than tall fescue treatments in both spring and summer though this was not significant (Table 3). Summergrow thrates were 21-35\% lower than in spring, with the largest drop on the tall fescue only treatments. There was no effect of ryegrass endophyte on animal growth rates.

The results in Table 4 show the substantially lower carrying capadity on the ryegrass treatments than on the

\section{Table 3 Average dally growth rate of yearting stags}

\begin{tabular}{lrcc}
\hline & & Growth Rate & (e/day) \\
& Spring & Summer & Mean \\
Hlgh endophyte ryegrass & 332 & 256 & 294 \\
Low endophyte ryegrass & 307 & 234 & 279 \\
Tall fescue & 302 & 196 & 249 \\
Tall fescue chicory/red clover & 296 & 235 & 265 \\
Lsd & 53 & 65 & 76 \\
\hline
\end{tabular}

Table 4 Grazing capacity of high and low endophyte ryegrass, tell fescue and tall fescue/chicory/red clover pastures one year after estab. lishment

$\begin{array}{cl}\begin{array}{c}\text { Number of grazing } \\ \text { days over }\end{array} & \text { liveweight gain } \\ \text { spring - summer' } & \text { (kg per ha/day) }\end{array}$

$\begin{array}{lcc}\text { High Endophyte ryegrass } & 1089 & 6.05 \\ \text { Low endophyte ryegrass } & 1769 & 5.52 \\ \text { Tall fescue } & 2326 & 6.40 \\ \text { Tall fescue/chicory/red clover } & 2470 & 7.17 \\ \text { Isd } & 460 & \end{array}$

1 Summation of animals and days of grazing (corrected to stag equivalents). tall fescue and tall fescue/ chicory mixture On the basis of total liveweight gain per ha, the tall fescue/ chicory mixture and the tall fescue pasture were more productive than the ryegrass pastures (Table 4).

\section{Discussion}

The drop in liveweight gain between spring and summer is characteristic of long-term liveweight gain studies, even when dover content in summer is markedly higher thaninspring (Stevensetaf. 1992,1993). The extra drop in performance of the tall fescue-only treatment, though not significant, has been observed before (Stevens unpub) and may be caused by a rapid dedine in digestibility of tall fescue leaf as it ages. Though high dry matter availability was maintained in the tall fescue pastures, patch grazing of new leaf became evident as the summer progressed.

The tall fescue and the tall fescue/ chicory/ red dover pastures gave $30 \%$ more grazing days than the ryegrass pastures without any significant reduction in per animal performance. The effect was probably bought about by the rapid depletion of soil nitrogen in the ryegrass plots because of rapid grass growth in autumn and early winter. Competition from the ryegrass also slowed white clover establishment, as was evident in late winter growing point numbers (Table 1). Hence the ryegrass pastures were nitrogen deficient during spring and early summer while tall fescue pastures with good dover development produced well.

Chicory contributed more to the green herbage in summer than in spring but this contribution was not as high as expected. This, coupled with the reduction in summer red clover content, may be the result of preferential grazing of these species (Hunt \& Hay 1990). especially under the short 20-day rotation through the summer. 
The mean spring/summer growth rate of the yearling stags compares well with the 7-year Jnvermay average of $242+/-13 \mathrm{~g} /$ day (Moore et al. 1988). Spring growth rates were very high and close to that reported by Barry (1991) on ryegrass. Barry's red clover growth rate of $366 \mathrm{~g} /$ day is higher than on the present experiment. This is understandable as the available dry matter in the current experiment was mainly grass in all treatments. The 1991/92 summer season was relatively wet and conditions did not affect adversely the ryegrass performance, as it was still 64-65\% of the available dry matter. The variable stocking regime used to ensure a high level of available dry matter did maintain a high growth rate on the ryegrass treatments, and no endophyte effects on animal growth were evident.

In a dry year animal growth rate as well as grazing days on ryegrass pastures would probably have been depressed owing to a declining availability of dry matter when compared with tall fescue based pastures. Wright et al. (1985) found no difference in animal performance between tall fescue- and ryegrass-based pastures in spring, but showed significant differences in a dry autumn. Behaviourial patterns appeared to be altered by high endophyte ryegrass. Deer on low cndophyte ryegrassand tall fescue-based pastures were quiet, easily handled and trained well to electric fences. The deer on the high endophyte pasture became flightly. hard to handle and could not be easily kept behind electric fences if disturbed. Ergovaline. a chemical which affects the animal's nervous system and is produced in high endophyte ryegrass, may be the cause of these apparent behaviourial problems.

Results from this first year's results show that deer liveweight gains can be high in both spring and summer on good pastures. High available dry matter levels and residues must be used and are most easily achieved by break grazing. Ryegrass endophyte had no effect on production. The better establishment of clover with tall fescue allowed much higher carrying capacities to be achieved while per head performance remained similar to that on ryegrass pastures. The first-year performance of tall fescue/chicory/red clover pastures was $24 \%$ and the tall fescue-alone pastures $11 \%$ more productive than the mean production from ryegrass pastures.

\section{ACKNOWLEDGEMENTS}

The authors wish to thank S Duncan, W Fraser, D Allan and Jnvermay farm staff for their able assistance to this research.

\section{REFERENCES}

Adam, J.L. 1988. Pasture for deer production. Proceedings of the New Zealand Grassland Association 49: $37-40$

Barry, T.N. 1991. Growth rates grow with red clover. The Deer Farmer 78: 35-37.

Hunt, W.F.; Hay, J.M. 1990. A photographic technique for assessing the pasture species performance of grazing animals. Proceedings of the New Zealand Grassland Association 51: 191-196.

McFarlane, A.W. 1990 Field experience with new pasture cultivars in Canterbury. Proceedingsof the New Zealand Grassland Association 51: 139144.

Moore, G.H.; Littlejohn, R.P.; Cowie, G.M. 1988. Liveweights. growth rates and mortality of fanned red deer at Jnvermay. New Zealand journal of agricultural research 31:293-300

Stevens, D.R.; Casey. M.J.; Lucas, R.J.; Baxter, G.S.; Miller, K.B. 1992. Angoragoatproductionfrom different legumes mixed with ryegrass. Proceedings of the New Zealand Society of Animal Production 52: In press

Stevens, D.R.; Baxter, G.S.; Casey. M.J.; Miller, K.B.; Lucas, R.J. 1993. A comparison of six grasses for animal production. Proceedings of the New Zealand Grassland Association 54: this vol

Stevens, D.R.; Hickey, M.J. 1989. Effects of endophyte ryegrass on the production of ryegrass/white clover pastures. Proceedings of the International Symposium on Acremonium/Grass Interactions Ed SS Quisenberry \& DE Joost. Baton Rouge.

The Deer Farmer 1992 June. Monthly Venison Schedule Analysis.

Wright, D.F.; Slay, M.W.A.; Hamilton, G.J.; Paterson,, D.J. 1985. Tall fescue for finishing lambs and' flushing ewes in Hawkes Bay. Proceedings of the New Zealand Grassland Association 46: 173-178. 